\title{
PENGARUH MOTIVASI, DISIPLIN KERJA, DAN GAYA KEPEMIMPINAN KEPALA SEKOLAH TERHADAP KINERJA GURU BAHASA INGGRIS SMP DKI JAKARTA
}

\author{
Supeno, Imam Suseno, Ira Miranti \\ Program Studi Bahasa Inggris, Fakultas Bahasa dan Seni \\ FBS Universitas Indraprasta PGRI Jakarta \\ supeno919@yahoo.com
}

\begin{abstract}
Abstrak
Penelitian ini bertujuan untuk mengetahui kinerja satuan pendidik yang kemudian dilihat pengaruhnya dari faktor motivasi, disiplin dan gaya kepemimpinan pimpinan lembaga pendidikan tersebut. Teropong utama tertuju pada kinerja guru bahasa Inggris Sekolah Menengah Pertama Jakarta. Sampel diperoleh melalui teknik cluster random sampling. Data kuantitatif dikumpulkan melalui kegiatan survei, melalui instrumen penelitian berupa angket dan wawancara yang bersifat terstruktur. Analisis data berupa regresi ganda. Hasil penelitian menyimpulkan bahwa (1) terdapat pengaruh motivasi terhadap kinerja guru bahasa Inggris, (2) terdapat pengaruh disiplin kerja terhadap kinerja guru bahasa Inggris, (3) terdapat pengaruh gaya kepemimpinan kepala sekolah terhadap kinerja guru bahasa Inggris, dan (4) terdapat pengaruh bersama antara motivasi, disiplin dan gaya kepemimpinan kepala sekolah terhadap kinerja guru bahasa Inggris.
\end{abstract}

Kata Kunci : Performance, motivasi, disiplin, dan leadership style

\begin{abstract}
This research is aimed at finding out the effect of motivation, discipline, and leadership style on teacher's performance. The main concern to emphasize on the performance of Junior High Schools teachers in Jakarta. The sampling technique employed is cluster random sampling and the data is collected by administering research instruments of questionnaire and interview while the path analysis is employed during data analysis. The research conclusions draw as follows: (1) there is an effect between motivation and teacher's performance, (2) there is an effect between discipline and teacher's performance, (3) there is an effect between leadership style of the headmaster and teacher's performance, and (4) there are effect of motivation, discipline, and leadership style altogether on teacher's performance.
\end{abstract}

Keywords: performance, motivation, discipline, and leadership style

\section{PENDAHULUAN}

Persoalan pendidikan sangat penting karena dari sana masa depan bangsa akan ditentukan oleh kualitas generasi muda yang lahir dari proses pendidikan. Pemerintah memberikan jaminan kualitas pendidikan bagi seluruh warga negaranya sebagaimana dalam UU No. 20/2003 Pasal 5, dinyatakan bahwa setiap warga negara mempunyai hak yang sama untuk memperoleh pendidikan yang bermutu. Untuk mencapai itu perlu mendapatkan per-hatian serius dari semua pihak yang berkepentingan, didukung dengan berbagai fasilitas penunjang pendidikan yang mamadai. Termasuk diantaranya persoalan guru. Guru sebagai pelaksana dilapangan yang bersentuhan langsung dengan peserta didik perlu mendapatkan 
dukungan dan dorongan yang sepenuhnya untuk melaksanakan tugas sebaikbaiknya.

Dalam menjalankan tugas guru dituntut menjadi profesional. Profesionalisme guru tertuang dalam Undang-undang No. 14 tahun 2005 pada Bab III pasal 7 ayat 1 menyatakan kedudukan guru sebagai tenaga profesional bertujuan untuk melaksanakan sistem pendidikan nasional dan mewujudkan tujuan pendidikan nasional, yaitu berkembangnya potensi peserta didik agar menjadi manusia yang beriman dan bertakwa kepada Tuhan Yang Maha Esa, berakhlak mulia, sehat, berilmu, cakap, kreatif, mandiri, serta menjadi warga negara yang demokratis dan bertanggung jawab.

Guru dituntut profesional, namun disisi lain muncul berbagai kendala/ hambatan/ masalah yang menyebabkan guru tidak dapat menjalankan tugasnya secara profesional. Imbas yang muncul adalah buruknya kinerja yang berimplikasi rendahnya mutu pendidikan. Gibson et. al (1985: 51-53) menyebutkan tiga kelompok variabel yang me-mengaruhi perilaku kinerja atau kinerja yaitu variabel individu, variabel organisasi dan variabel psikologi. Variabel individu dan psikologi termasuk di dalamnya adalah motivasi dan disiplin diri, sedangkan dari variabel organisasi di antaranya adalah kepemimpinan.

Memperhatikan masalah tersebut, berkaitan dengan kinerja guru bahasa Inggris mungkin dapat dilihat dari faktor motivasi, disiplin dan gaya kepemimpin-an kepala sekolah. Ketiga faktor tersebut sangat dimungkinkan mempengaruhi kinerja guru bahasa Inggris. Kinerja guru bahasa Inggris yang baik sangat di-butuhkan dalam proses belajar mengajar. Jendela menuju gerbang ilmu pe-ngetahuan dan pergaulan diera globalisasi adalah penguasaan bahasa Inggris dengan baik. Tanpa adanya kinerja guru bahasa Inggris yang baik mustahil tujuan pendidikan bahasa Inggris dapat tercapai dengan baik.

Tujuan yang ingin dicapai dalam penelitian ini adalah menentukan adakah pengaruh motivasi kerja terhadap disiplin kerja guru bahasa Inggris, disiplin, dan gaya kepemimpinan kepala sekolah secara parsial dan simultan terhadap kinerja guru bidang studi Bahasa Inggris pada pada tingkat Sekolah Menengah Pertama di DKI Jakarta.

\section{TINJAUAN PUSTAKA}

Kinerja adalah hasil pekerjaan yang dicapai seseorang berdasarkan persyaratan-persyaratan pekerjaan (job requirement) (Bangun, 2012: 231). Artinya bahwa suatu pekerjaan mempunyai persyaratan tertentu untuk dapat dilakukan dalam mencapai tujuan yang disebut juga standar pekerjaan (job standard). Kinerja seorang dapat dinilai berdasarkan jumlah pekerjaan yang diselesaikan, sesuai standar dan dalam batas waktu tertentu.

Penilaian kinerja merupakan proses suatu organisasi berupaya memperoleh informasi yang seakurat mungkin tentang kinerja anggotanya. Manfaat penilaian kinerja dapat dikaitkan dengan upaya meningkatkan produktivitas kerja organisasi, produktivitas kerja berbagai komponen organisasi dan sebagai pendorong bagi para karyawan (Siagian, 2009: 168). Oleh karena itu, penilaian kinerja harus dilakukan secara tepat karena akan sangat bermanfaat bagi organisasi secara keseluruhan, bagi atasan langsung dan bagi karyawan bersangkutan.

Guru dalam UU No. 14 Tahun 2005 didifinisikan sebagai pendidik 
profesional dengan tugas utama mendidik, mengajar, membimbing, mengarahkan, melatih, menilai dan mengevaluasi peserta didik pada pendidikan anak usia dini jalur formal pendidikan formal, pendidikan dasar, dan pendidikan menengah. Selanjutnya Pasal 20 dalam tugas keprofesionalan guru berkewajiban merencanakan pembelajaran, melaksanakan proses pembelajaran yang bermutu, serta menilai dan mengevaluasi hasil pembelajaran. Jadi guru merupakan satuan anggota organisasi sekolah yang melaksanakan tugas dan kewajibannya sebagai seorang pendidik yang profesional.

Permen Diknas 35 Tahun 2010 mendefinisikan kinerja guru sebagai hasil penilaian terhadap proses dan hasil kerja yang dicapai guru dalam melaksanakan tugasnya. Sedangkan penilaian kinerja guru adalah penilaian dari tiap butir kegiatan dan atau akumulasi nilai butir-butir kegiatan yang harus dicapai oleh seorang guru dalam rangka pembinaan karir kepangkatan dan jabatannya. Dimana tugas utama seorang guru adalah mendidik, mengajar, membimbing, mengarahkan, melatih, menilai dan mengevaluasi peserta didik pada pendidikan anak usia dini dijalur pendidikan formal, pendidikan dasar, dan pendidikan menengah.

Dalam melaksanakan tugas, guru perlu memiliki tiga kemampuan dasar agar kinerjanya tercapai sebagai berikut: 1) kemampuan pribadi meliputi hal-hal yang bersifat fisik seperti tampang, suara, mata atau pandangan, kesehatan, pakaian, pendengaran, dan hal yang bersifat psikis seperti humor, ramah, intelek, sabar, sopan, rajin, kreatif, kepercayaan diri, optimis, kritis, obyektif, dan rasional; 2) kemampuan sosial antara lain bersifat terbuka, disiplin, memiliki dedikasi, tanggung jawab, suka menolong, bersifat membangun, tertib, bersifat adil, pemaaf, jujur, demokratis, dan cinta anak didik; 3) kemampuan profesional meliputi: menguasai bidang studi dalam kurikulum sekolah dan menguasai bahan pendalaman/aplikasi bidang studi, mengelola program belajar pengajar, mengelola kelas, menggunakan media dan sumber, menguasai landasan-landasan kependidikan, mengelola interaksi belajar mengajar, menilai prestasi siswa untuk kepentingan pen-didikan, mengenal fungsi dan program bimbingan penyuluhan, mengenal dan menyelenggarakan administrasi sekolah, memahami prinsip dan menafsirkan hasil-hasil penelitian pendidikan guna keperluan mengajar (Aritonang, 2005: 5).

Faktor-faktor yang memengaruhi kinerja individu sebagai tenaga kerja adalah faktor kemampuan (ability) dan faktor motivasi (motivation) hal ini sesuai dengan pendapat Keith Davis (1964) dalam Mangkunegara (2001:67) berikut:

Human performance $=$ Ability + motivation Motivation = Attitude + situation Ability $=$ Knowledge + Skill

Motivasi diartikan sebagai daya upaya yang mendorong seseorang untuk melakukan sesuatu. Artinya motivasi dapat dikatakan sebagai daya penggerak dari dalam dan didalam subjek untuk melakukan kegiatan-kegiatan tertentu guna mencapai suatu tujuan (Sardiman, 1990: 73).

Guru bermotivasi mengajar tinggi ditandai beberapa karakteristik perilaku yaitu rajin mengajar dikelas, bergairah dalam mengajar, aktif dan kreatif dalam melakukan pembaruan dalam bidang pendidikan untuk keperluan pembelajaran dikelas, berprilaku produktif dan inovatif dalam mengajar, dan beretos kerja tinggi sehingga tidak mengenal 
lelah dalam mengajar dan mudah putus asa jika menemukan kesulitan dalam menekuni kariernya sebagai pengajar dan pendidik disekolah (Hadis, 2006: 28).

Hakikat disiplin diartikan sebagai suatu kekuatan yang berkembang di dalam tubuh pekerja sendiri yang menyebabkan dia dapat menyesuaikan diri dengan sukarela kepada keputusankeputusan, peraturan-peraturan, dan nilai-nilai tinggi dari pekerjaan dan tingkah laku (Mangkunegara, 2001: 129), sedangkan sedarmayanti (2001: 10) menegaskan bahwa disiplin merupakan salah satu fungsi manajemen sumber daya manusia yang penting dan merupakan kunci terwujudnya tujuan, karena tanpa adanya disiplin maka sulit mewujudkan tujuan yang maksimal. Maksudnya melalui usaha pendisiplinan akan timbul kesadaran dan keinginan karyawan untuk menaati peraturan organisasi dan norma sosial. Namun tetap pengawasan terhadap pelaksanaan disiplin tersebut perlu dilakukan. Disiplin kerja merupakan kemampuan seseorang untuk secara teratur, tekun secara terusmenerus dan bekerja sesuai dengan aturan-aturan yang berlaku dengan tidak melanggar aturan-aturan yang sudah ditetapkan. Pada dasarnya banyak

Disiplin merupakan tindakan manajemen untuk mendorong para anggota organisasi memenuhi tuntutan berbagai ketentuan atau peraturan tersebut. Disiplin kerja dapat diartikan sebagai pelaksanan manajemen untuk memperteguh pedoman-pedoman organisasi. Indikator yang mempengaruhi tingkat kedisplinan karyawan suatu organisasi di antaranya ialah: 1) tujuan dan kemampuan, 2) teladan pimpinan, 3) balas jasa (gaji dan kesejahteraan), 4) keadilan, 5) waskat (pengawasan melekat), 6) sanksi hukuman, 7) ketegasan, dan 8) hubungan kemanusiaan (Hasibuan, 1997: 213).

Hasibuan (1997: 193-194) berpendapat kedisiplinan adalah kesadaran dan kesediaan seseorang menaati semua peraturan perusahaan dan norma-norma sosial yang berlaku. Kesadaran disini merupakan sikap seseorang yang secara sukarela menaati semua peraturan dan sadar akan tugas dan tanggung jawabnya. Artinya dia akan mematuhi atau mengerjakan semua tugasnya dengan baik, bukan atas paksaan. Sedangkan kesediaan adalah suatu sikap, tingkah laku, dan perbuatan seseorang yang sesuai dengan peraturan perusahaan, baik yang tertulis maupun tidak tertulis.

Melalui disiplin pula timbul keinginan dan kesadaran untuk menaati peraturan organisasi dan norma sosial. Namun tetap pengawasan terhadap pelaksanaan disiplin tersebut perlu dilakukan. Jadi disiplin kerja bagi guru adalah persepsi guru terhadap sikap pribadi guru dalam hal ketertiban dan keteraturan diri yang dimiliki oleh guru dalam bekerja di sekolah tanpa ada pelanggaran-pelanggaran yang merugikan dirinya, orang lain, atau lingkungannya.

Kepemimpinan diartikan sebagai pengaruh, seni, atau proses mempengaruhi orang-orang sehingga mereka akan berusaha dalam mencapai tujuan kelompok dengan kemauan dan antusias (Koontz, et. al dalam Bangun, 2012: 338). Artinya bahwa kepemimpinan dipandang sebagai kemampuan untuk mempengaruhi kelompok dalam mencapai tujuan organisasi. Kemampuan mempengaruhi tidak dapat dilaksanakan begitu saja, oleh karena itu diperlukan juga seni untuk menjadikan orang lain memiliki tanggung jawab dan bersemangat dalam mencapai tujuan yang telah ditetapkan. 
Kepemimpinan merupakan suatu faktor penting untuk menentukan prilaku individu dan kelompok dalam organisasi. Kesalahan dalam menentukan gaya kepemimpinan akan berdampak pada penurunan kinerja, tingginya tingkat absensi dan tidak tercapainya tujuan organisasi. Kepala sekolah juga dikatakan sebagai seorang pemimpin, kepemimpinannya di sekolah merupakan tugas untuk mengelola dan menggerakan organisasi kependidikan pada wilayah satu sekolah. Seorang kepala sekolahpun harus mampu menentukan gaya kepemimpinan yang tepat sehingga visi dan misi sekolah yang diembannya dapat tercapai dengan baik.

Gaya kepemimpinan) diketahui ada lima tipe/gaya pemimpin yaitu 1) gaya pemimpin yang otoriter, 2) gaya paternalistik, 3) gaya laissez faire, 4) gaya demokratik, 5) gaya karismatik. Lebih lanjut Siagian (2009: 92) memandang gaya kepemimpinan sebagai salah satu aspek yang dominan dan krusial bahkan kritikal dalam upaya meningkatkan produktivitas kerja.

Leadership style yang dikaitkan dengan tingkat kedewasaan para bawahan Siagian (2009: 92) menggolongkan empat tingkat kedewasaan bawahan yaitu: para bawahan tidak mampu dan tidak mampu (K-1), para bawahan tidak mampu meskipun ada kemauan untuk berbuat semaksimal mungkin (K-2), para bawahan sebenarnya mampu tetapi perilakunya negatif (K-3), para bawahan mampu dan mau (K-4). Artinya bahwa tidak ada satu gaya kepemimpinan yang sama efektif meng-hadapi semua situasi organisasi dan perilaku bawahan. Bahkan manghadapi seorang bawahan mungkin meng-gunakan gaya yang berbeda-beda karna bawahan itu tidak konsisten dalam perilakunya. Untuk itu bagaimana pola dan metode yang diterapkan kepala sekolah melalui gaya kepemimpinannya akan mempengaruhi para guru dalam mengajar dan murid untuk belajar.

Efektivitas mengajar guru akan optimal, jika kepala sekolah dapat mengatur dan membimbing guru-guru secara baik sehingga para guru dapat melaksanaka tugas-tugasnya dengan penuh tanggung jawab, memperhatikan kepentingan dan kesejahteraan bawahannya sehingga tidak ada keluhan dalam menjalankan tugas dan kewajiban sehari-hari, harus menunjukkan kewibawaannya sehari-hari, sehingga dapat diteladani dan dipatuhi oleh para guru maupun siswa. Menetapkan dan sekaligus melaksanakan peraturanperaturan yang logis dan sistematis, dan dapat diterima oleh semua pihak yang terkait dalam peningkatan efektifitas mengajar guru.

\section{METODE PENELITIAN}

Penelitian ini merupakan penelitian survei yang dilaksankan pada bulan Juli 2014 sampai bulan September 2014. Berdasarkan karakteristik dari populasi maka sempel penelitian ditetapkan sebanyak 163 guru dengan teknik cluster random sampling. Data dikumpulkan menggunakan angket berupa pernyataan terkait motivasi, disiplin dan gaya kepemimpinan kepala sekolah yang diisi oleh guru bahasa Inggris itu sendiri. Sedang penilaian kinerja guru bahasa Inggris diisi oleh kepala sekolah/wakil ataupun guru senior dari guru tersebut. Instrumen penelitian telah diuji validitas melalui expert judgemen serta validitas empiris, dan uji reliabilitas instrumen. Analisis data penelitian menggunakan analisis jalur (path analysis) melalui program analisis statistika yaitu SPSS versi 17,00 . 
HASIL DAN PEMBAHASAN

Deskripsi statistik terhadap tiga variabel bebas dan satu variabel terikat berupa; nilai rerata (mean), nilai tengah (median), nilai yang sering muncul (modus), simpangan baku dan nilai varians. Terlihat pada rekapitulasi deskripsi statistik hasil penelitian sebagai berikut:

Tabel 1. Rekapitulasi Deskripsi Statistik

\begin{tabular}{|l|c|c|c|c|}
\hline \multicolumn{1}{|c|}{ Jenis Data } & Rerata & $\begin{array}{c}\text { Median } \\
(\mathbf{M e})\end{array}$ & $\begin{array}{c}\text { Modus } \\
(\mathbf{M o})\end{array}$ & $\begin{array}{c}\text { Standar } \\
\text { Deviasi } \\
(\mathbf{S})\end{array}$ \\
\hline Kinerja Guru Bahasa Inggris & 97,08 & 97,00 & 90,00 & 7,46 \\
\hline Motivasi Kerja & 82,42 & 84,00 & 84,00 & 7,57 \\
\hline Disiplin Kerja & 96,41 & 99,00 & 100 & 7,69 \\
\hline $\begin{array}{l}\text { Gaya Kepemimpinan Kepala } \\
\text { Sekolah }\end{array}$ & 52,72 & 53,00 & 58,00 & 5,76 \\
\hline
\end{tabular}

Data Kinerja Guru Bahasa Inggris dikumpulkan dengan 30 butir pertanyaan dan melalui 4 pilihan jawaban diperoleh nilai rerata 97,08 artinya kinerja sampel penelitian berstatus sangat baik. Adapun dimensi operasional dari kinerja guru bahasa Inggris dalam melaksanakan tugas pembelajaran dikelas terlihat pada tabel berikut:

Tabel 2. Rekapitulasi Kinerja Guru Bahasa Inggris

\begin{tabular}{|c|c|c|c|c|c|c|}
\hline \multirow{2}{*}{ Keterangan } & \multicolumn{2}{|c|}{$\begin{array}{c}\text { Perencanaan } \\
\text { Pembelajaran }\end{array}$} & \multicolumn{2}{c|}{$\begin{array}{c}\text { Pelaksanaan } \\
\text { Pembelajaran }\end{array}$} & \multicolumn{2}{c|}{ Evaluasi/Penilaian } \\
\cline { 2 - 7 } & Jumlah & $\%$ & Jumlah & $\%$ & Jumlah & $\%$ \\
\hline Tidak Memenuhi Standar & & $0.00 \%$ & - & $0.00 \%$ & - & $0.00 \%$ \\
\hline Dibawah Standar & 17 & $10.43 \%$ & 19 & $11.66 \%$ & 21 & $12.88 \%$ \\
\hline Memenuhi Standar & 53 & $32.52 \%$ & 67 & $41.10 \%$ & 98 & $60.12 \%$ \\
\hline Diatas Standar & 94 & $57.67 \%$ & 77 & $47.24 \%$ & 44 & $26.99 \%$ \\
\hline Total & 163 & $100.00 \%$ & 163 & $100.00 \%$ & 163 & $100.00 \%$ \\
\hline
\end{tabular}

Sedangkan data variabel motivasi kerja diperoleh melalui 19 butir pernyatan dan 5 pilihan jawaban diperoleh nilai rerata 82,43 artinya ratarata responden memiliki motivasi kerja sangat baik. Persentase dari responden ditemukan 19,63\% memiliki motivasi baik dan sebanyak $79,14 \%$ motivasi kerja sangat baik.

Data disiplin kerja diperoleh dari 21 butir pernyatan dan 5 pilihan jawaban diperoleh nilai rerata 96,41 artinya rata-rata responden memiliki sikap disiplin kerja yang sangat baik. Persentase dari responden ditemukan
$19,02 \%$ ber-disiplin baik dan 80,98\% berdisiplin kerja sangat baik.

Sedangkan data gaya kepemimpin-an Kepala Sekolah menggunakan 13 butir pernyatan dan 5 pilihan jawaban diperoleh nilai rerata 52,72 artinya rata-rata responden menilai gaya ke-pemimpinan kepala sekolah sangat baik. Dan persentase dari responden ditemukan 4,29\% berpendapat kepala sekolah memiliki kepemimpinan yang sedang, sebanyak 44,18\% memiliki kepemimpinan yang baik dan 51,53\% guru bahasa Inggris 
menilai gaya kepemimpinan kepala sekolah berada pada tingkat sangat baik.

\section{UJI PERSYARATAN ANALISIS Normalitas Galat Taksiran}

Uji persyaratan normalitas dilakukan terhadap galat taksiran regresi kinerja guru bahasa Inggris (Y) atas motivasi kerja $\left(\mathrm{X}_{1}\right)$, kinerja guru bahasa
Inggris ( $\mathrm{Y}$ ) atas kepemimpinan kepala sekolah $\left(\mathrm{X}_{2}\right)$, kinerja guru bahasa Inggris $(\mathrm{Y})$ atas disiplin kerja $\left(\mathrm{X}_{3}\right)$, disiplin kerja guru bahasa Inggris $\left(\mathrm{X}_{3}\right)$ atas motivasi kerja $\left(\mathrm{X}_{1}\right)$ dan disiplin kerja $\left(\mathrm{X}_{3}\right)$ atas kepemimpinan kepala sekolah $\left(\mathrm{X}_{2}\right)$ dengan menggunakan rumus lilliefors

Tabel 3. Rangkuman Uji Normalitas Galat Taksiran

\begin{tabular}{|l|c|c|c|c|c|l|}
\hline \multirow{2}{*}{ No } & \multirow{2}{*}{ Galat Taksiran } & \multirow{2}{*}{$\mathrm{N}$} & \multirow{2}{*}{ Lhitung } & \multicolumn{2}{|c|}{$\mathrm{L}_{\text {tabel }}$} & \multirow{2}{*}{ Keterangan } \\
\cline { 5 - 6 } & & & & $\alpha=0,05$ & $\alpha=0,01$ & \\
\hline 1 & $\mathrm{Y}$ atas $\mathrm{X}_{1}$ & 163 & 0,079 & 0,069 & 0.081 & Normal \\
\hline 2 & $\mathrm{Y}$ atas $\mathrm{X}_{2}$ & 163 & 0,040 & 0,069 & 0.081 & Normal \\
\hline 3 & $\mathrm{Y}$ atas $\mathrm{X}_{3}$ & 163 & 0,075 & 0,069 & 0.081 & Normal \\
\hline 4 & $\mathrm{X}_{3}$ atas $\mathrm{X}_{1}$ & 163 & 0,071 & 0,069 & 0.081 & Normal \\
\hline 5 & $\mathrm{X}_{3}$ atas $\mathrm{X}_{2}$ & 163 & 0,076 & 0,069 & 0.081 & Normal \\
\hline
\end{tabular}

Berdasarkan rangkuman uji normalitas kelima galat taksiran terbukti berdistribusi normal.

\section{Uji Signifikansi dan Linearitas Model Regresi}

Persyaratan terakhir ini harus dipenuhi dalam melakukan analisis jalur, variabel-variabel bebas yang dirumuskan dalam teoritik mempunyai hubungan linear secara nyata. Oleh karena itu, dilakukan uji signifikansi dan linearitas model regresi linear sesuai dengan model hubungan antar variabel yang dirumuskan dalam model hipotetik. Hasil uji signifikansi dan linearitas model regresi linear diperoleh sebagai berikut:

Tabel 4. Uji Signifikansi dan Linearitas Model Regresi

\begin{tabular}{|c|c|l|}
\hline Keterangan & Persamaan & \multicolumn{1}{|c|}{ Status } \\
\hline $\mathrm{Y}$ atas $\mathrm{X}_{1}$ & $\hat{\mathrm{Y}}=78,816+0,220 . \mathrm{X}_{1}$ & Signifikan dan Linear \\
\hline $\mathrm{Y}$ atas $\mathrm{X}_{2}$ & $\hat{\mathrm{Y}}=66,886+0,575 . \mathrm{X}_{2}$ & Signifikan dan Linear \\
\hline $\mathrm{Y}$ atas $\mathrm{X}_{3}$ & $\hat{\mathrm{Y}}=73,241+0,249 . \mathrm{X}_{3}$ & Signifikan dan Linear \\
\hline $\mathrm{X}_{3}$ atas $\mathrm{X}_{1}$ & $\mathrm{X}_{3}=40,568+0,664 . \mathrm{X}_{1}$ & Signifikan dan Linear \\
\hline $\mathrm{X}_{3}$ atas $\mathrm{X}_{2}$ & $\mathrm{X}_{3}=68,781+0,507 . \mathrm{X}_{2}$ & Signifikan dan Linear \\
\hline
\end{tabular}

Sebelum melakukan pengujian model, analisis regresi sederhana untuk maka salah satu syarat yang harus pengujian linearitas, telah dihasilkan terpenuhi adalah adanya korelasi yang koefisien korelasi variabel bebas dengan signifikan antara variabel berkait. Dari variabel terikat sebagai berikut:

Tabel 5. Rekapituasi Uji Signifikansi Koefisien Korelasi

\begin{tabular}{|c|c|c|c|c|}
\hline \multirow{2}{*}{ Hubungan } & \multirow{2}{*}{ Koefisien Korelasi } & \multirow{2}{*}{$t_{\text {hitung }}$} & \multicolumn{2}{|c|}{$\mathrm{t}_{\text {tabel }}$} \\
\cline { 3 - 5 } & & 2,869 & $\alpha=0,05$ & $\alpha=0,01$ \\
\hline $\mathrm{X}_{1}$ dengan $\mathrm{Y}$ & 0,221 & 6,669 & 1,645 & 2,326 \\
\hline $\mathrm{X}_{2}$ dengan $\mathrm{Y}$ & 0,465 & 3,335 & 1,645 & 2,326 \\
\hline $\mathrm{X}_{3}$ dengan $\mathrm{Y}$ & 0,254 & 10,893 & 1,645 & 2,326 \\
\hline $\mathrm{X}_{1}$ dengan $\mathrm{X}_{3}$ & 0,651 & 5,568 & 1,645 & 2,326 \\
\hline $\mathrm{X}_{2}$ dengan $\mathrm{X}_{3}$ & 0,402 & \multicolumn{3}{|c}{} \\
\hline
\end{tabular}


Hasil perbandingan menunjukkan $t_{\text {hitung }}>t_{\text {tabel }}$ pada semua hubungan tersebut diatas maka ke lima hubungan antar variabel bersifat signifikan.

Hasil akhir persamaan struktural secara total variabel eksogen terhadap variabel endogen yang terlihat pada nilai koefisien jalur (path coefficient) dari data yang telah dikumpulkan dapat dijelaskan model kausal empiris dalam bentuk gambar path analysis sebagai berikut:

Gambar 1. Model Akhir Diagram Jalur

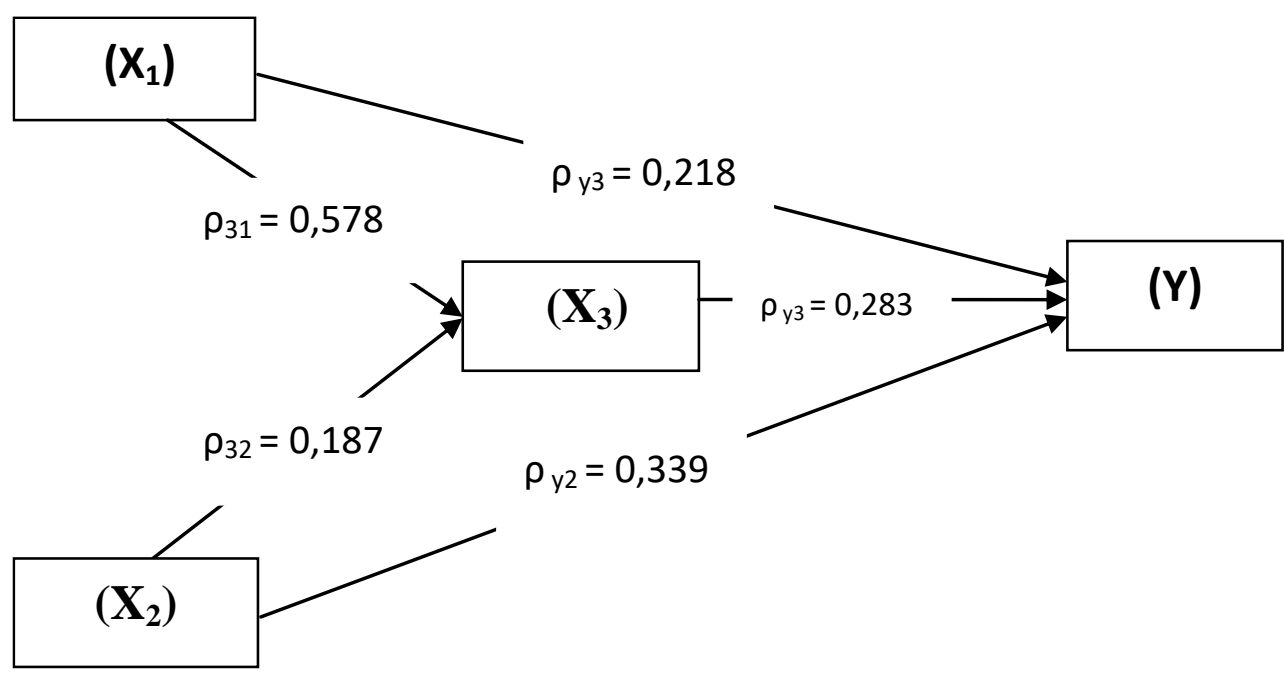

Gambar 1 Model akhir diagram jalur menunjukkan adanya pengaruh langsung maupun tidak langsung antara variabel endogen yaitu motivasi kerja, variabel disiplin kerja dan variabel gaya kepemimpinan kepala sekolah terhadap variabel eksogen kinerja guru bahasa Inggris di DKI Jakarta.

\section{PEMBAHASAN}

Pengaruh motivasi kerja $\left(\mathrm{X}_{1}\right)$ terhadap disiplin kerja guru Bahasa Inggris $\left(\mathrm{X}_{3}\right)$ terlihat pada gambar 1 menunjukkan adanya pengaruh yang positif. Besaran koefisien jalur $\rho_{31}=$ 0,578 dan nilai signifikansi diperoleh $t_{\text {hitung }}=8,592$ serta $t_{\text {tabel }}=1,90$ (thitung $>$ $\left.\mathrm{t}_{\text {tabel}}\right)$, sehingga data penelitian yang dikumpulan mendukung pernyatan bahwa motivasi kerja berperan dalam pembentukan sikap disiplin kerja guru bahasa Inggris.
Pengaruh Gaya Kepemimpinan kepala Sekolah $\left(\mathrm{X}_{2}\right)$ dan disiplin kerja guru bahasa Inggris $\left(\mathrm{X}_{3}\right)$ menunjukkan adanya pengaruh positif dan signifikan. Dengan nilai koefisien jalurnya $\rho_{32}=$ 0,187 dan nilai signifikasi diperoleh $\mathrm{t}_{\text {hitung }}=2,775$ sedangkan $\mathrm{t}_{\text {tabel }}=1,90$ ( $\left.t_{\text {hitung }}>t_{\text {tabel }}\right)$. Sehingga berdasarkan data yang dikumpulan mendukung pernyatan bahwa gaya kepemimpinan kepala sekolah berperan dalam upaya pembentukan disiplin kerja guru bahasa Inggris.

Pengaruh motivasi $\left(\mathrm{X}_{1}\right)$ dan Kinerja Guru bahasa Inggris (Y) menunjukkan adanya pengaruh positif dan signifikan. Dengan nilai koefisien jalurnya $\rho_{\mathrm{y} 1}=0,218$ dan nilai signifikansi diperoleh $t_{\text {hitung }}=2,170$ sedangkan $t_{\text {tabel }}=1,90 \quad\left(t_{\text {hitung }}>t_{\text {tabel }}\right)$, sehingga Ini menunjukkan data yang dikumpulan mendukung pernyataan bahwa motivasi kerja berperan dalam 
upaya pembentukan kinerja guru bahasa Inggris.

Pengaruh gaya kepemimpinan kepala sekolah $\left(\mathrm{X}_{2}\right)$ dan kinerja guru bahasa Inggris (Y) menunjukkan adanya pengaruh positif dan signifikan. Dengan nilai koefisien jalur yang diperoleh $\rho_{\mathrm{y} 2}=0,339$ dan nilai signifikansi diperoleh $t_{\text {hitung }}=3,813$ dan $t_{\text {tabel }}=1,90 \quad\left(t_{\text {hitung }}>t_{\text {tabel }}\right) . \quad$ Ini menunjukkan data yang dikumpulan mendukung pernyataan bahwa gaya kepemimpinan kepala sekolah sangat berperan dalam upaya pembentukan kinerja guru bahasa Inggris

Pengaruh disiplin kerja $\left(\mathrm{X}_{3}\right)$ terhadap kinerja guru bahasa Inggris (Y) menunjukkan adanya pengaruh positif dan signifikan. Dengan nilai koefisien jalurnya $\rho_{\mathrm{y} 3}=0,283$ dan nilai signifikansi diperoleh $t_{\text {hitung }}=2,813$ dan $\mathrm{t}_{\text {tabel }}=1,90 \quad\left(\mathrm{t}_{\text {hitung }}>\mathrm{t}_{\text {tabel }}\right) . \quad$ Ini menunjukkan data yang dikumpulan mendukung pernyataan bahwa disiplin kerja sangat berperan dalam upaya pembentukan kinerja guru bahasa Inggris.

Hasil penelitian mendukung pernyataan bahwa kinerja guru bahasa Inggris dipengaruhi oleh motivasi, gaya kepemimpinan kepala sekolah dan disiplin kerja guru bahasa Inggris. Pengaruh terbesar kinerja guru ternyata dipengaruhi oleh variabel gaya kepemimpinan kepala sekolah, kemudian disiplin dan motivasi. Artinya tinggi dan rendahnya kinerja guru bahasa Inggris khususnya di DKI Jakarta akan sangat diperngaruh faktor eksternal. Faktor eksternal tersebut adalah gaya kepemimpinan kepala sekolah, maka bisa jadi ketika gaya kepemimpinan kepala sekolah yang cocok dan baik akan mempengaruhi disiplin dan motivasi kerja guru bahasa Inggris, sehingga akan meningkatkan kinerja guru bahasa Inggris, dan sebaliknya.

\section{SIMPULAN}

Berdasarkan hasil analisis terhadap pengaruh langsung dan tidak langsung variabel endogen dan eksogen melalui path analysis diperoleh simpulan sebagai berikut:

1. Kualitas kinerja guru bahasa Inggris di SMP DKI Jakarta berada pada peringkat baik dan sangat baik.

2. Terdapat pengaruh motivasi kerja terhadap disiplin guru bahasa Inggris di SMP DKI Jakarta.

3. Terdapat pengaruh pengaruh gaya kepemimpinan kepala sekolah terhadap disiplin kerja guru bahasa Inggris di SMP DKI Jakarta

4. Terdapat pengaruh motivasi kerja terhadap kinerja guru bahasa Inggris di SMP DKI Jakarta.

5. Terdapat pengaruh gaya kepemimpinan kepala sekolah terhadap kinerja guru bahasa Inggris di SMP DKI Jakarta

6. Terdapat pengaruh disiplin kerja terhadap kinerja guru bahasa Inggris di SMP DKI Jakarta.

\section{DAFTAR PUSTAKA}

Agung, I G Ngurah. (2014). Managemen Penyajian Analisis Data Sederhana. Jakarta: RajaGrafindo Persada.

Aritonang, Keke T. (2005). Kompensasi kerja, disiplin kerja guru dan kinerja guru SMP kristen BPK Penabur Jakarta. Jakarta: Jurnal Pendidikan Penabur.

Bangun, Wilson. (2012). Managemen Sumber Daya Manusia. Jakarta: Erlangga.

Bernard, H W. (1970). Mental Health in The Classroom (New York: McGraw-Hill Book Company. 
Gibson. Et. Al. (1985). Organisasi: Perilaku, Struktur dan Proses. (Jakarta: Erlangga).

Hadis, Abdul. (2006). Psikologi dalam Pendidikan. Bandung: Alfabeta.

Hasibuan, Melayu. (1997). Managemen Sumber Daya Manusia. Jakarta: Gunung Agung.

Lester D. Crow and Alice Crow. (1965). Human Development and Learning (New York: American Book Company.

Mangkunegara, A, Prabu. (2001). Managemen Sumber Daya Manusia Perusahaan. Bandung: PT. Rosdakarya.

Mathis, Robert L. Jackson, John H. (2001). Manajemen Sumber Daya Manusia. Jakarta: Salemba. 2002. Manajemen Sumber Daya Manusia. Jakarta: Salemba

Nazir, Moh. 2005. Metode Penelitian. Jakarta: Ghalia.

Sardiman, A.M. (1990). Interaksi dan Motivasi Belajar Mengajar. Jakarta: Rajawali Pers.

Sedarmayanti. (2001). Sumber Daya Manusia dan Produktivitas Kerja. Bandung: CV Mandar Maju.

Senge, P.M. (1996). Disiplin kelima, seni dan praktek organisasi pembelajar, terjemahan Nunuk Adiarni (Jakarta: Binarupa Aksara, 1996.

Slameto. (1988). Belajar dan Faktorfaktor yang Mempengaruhinya. Jakarta: Bina Aksara.

Siagian, Sondang P. (2009). Kiat Meningkatkan Produktivitas Kerja. Jakarta: Rineka Cipta.

Sugiyono. (2010). Metode Penelitian kuantitatif dan kualitatif serta $R \& D$. Bandung: Alfabeta.

Supardi. (2013). Kinerja Guru. Jakarta: Raja Grafindo Persada.

Supranto. (2010). Analisis Multivariat Arti dan Interpretasi. Jakarta: Rineka Cipta.

Uno, Hamzah, B. Lamatenggo, Nina. (2012). Teori Kinerja dan Pengukurannya. Jakarta: Bumi Aksara

Usman, H. (2004). Metodelogi Penelitian Sosial. Jakarta: Bumi Aksara

W. W. Wayson. (2014). Opening windows to teaching: empowering educators to teach self-discipline, Journal of the College of Education, theory into practice, USA, Vol.xxiv, no, $4, \quad$ dalam (www.journaleducation.ac.id/sel f-discipline/). 